UDC: $598.2: 591.5](477.83-25-021)$

\title{
ANNUAL DYNAMICS OF BIRD COMMUNITIES IN URBAN PARKS IN LVIV, UKRAINE: PRELIMINARY ANALYSIS OF DIVERSITY AND COMPOSITION VARIABILITY
}

\section{O. Dubovyk}

Ivan Franko National University of Lviv, 4, Hrushevskyi St., Lviv 79005, Ukraine e-mail: oadubovyk@gmail.com

Dubovyk O. Annual dynamics of bird communities in urban parks in Lviv, Ukraine: preliminary analysis of diversity and composition variability. Studia Biologica, 2019: 13(2); 79-98 • DOI: https:// doi.org/10.30970/sbi.1302.598

Species and numeric composition of bird communities were analyzed in parks of Lviv based on results of monthly censuses on 20 linear transects on eight study plots. During the year, 79 bird species that belong to eight taxonomic orders were registered Birds' diversity was assessed by species number and Simpson index and it varies throughout the year and denotes higher level during the breeding season. Similarly, birds' density is the highest in breeding season, but it also has a less expressed peak in winter period. This shows that biotopical preferences to be presented in urban greenery of particular birds are especially notable only while breeding, but in non-breeding season those birds stay resident in scale of the city though disperse in other habitat types. Between-months, stability of species composition (assessed by Jaccard index) and numeric composition (by BrayCurtis index) was analyzed. Communities were the most stable during the breeding season as birds are related to their nesting sites. According to zoogeographic classification, European species dominate during all months. Siberian, Transpalearctic and Mediterranean species also play role in forming of the community structure. The main food resources type which compensates energy demands of birds during the breeding season is invertebrates; this shows the importance of birds in controlling the abundance of invertebrates in urban ecosystems. Seeds are also important food resource types, especially during the non-breeding period. Abundance variability of part of species is related with season. Three main groups of these species were defined: breeding migrants (mainly songbirds such as Fringilla coelebs, Erithacus rubecula, Sylvia atricapilla, Phylloscopus collybita etc., also Columba palumbus), wintering migrants (Spinus spinus, Turdus viscivorus, Bombycilla garrulus, Pyrrhula pyrrhula) and residents (typical synanthropic species whose numbers vary: Turdus merula, Coccothraustes coccothraustes, Troglodytes

(C) 2019 О. Dubovyk; Published by the Ivan Franko National University of Lviv on behalf of Біологічні Студії / Studia Biologica. This is an Open Access article distributed under the terms of the Creative Commons Attribution License (http://www.budapestopenaccessinitiative.org/ and Creative Commons Attribution 4.0 License), which permits unrestricted reuse, distribution, and reproduction in any medium, provided the original work is properly cited.

ISSN 1996-4536 (print) • ISSN 2311-0783 (on-line) • Біологічні Студії / Studia Biologica • 2019 • Том 13/№2 • С. 79-98 
troglodytes, Cyanistes caeruleus etc.). The last ones, probably, migrate in non-breeding seasons to other habitat types, that can explain their abundance variability.

Keywords: seasonal variation, urban ecosystems, synanthropic species, bird species composition, urban forest, bird community

\section{INTRODUCTION}

The consequences of urbanization processes on wildlife are known widely: economic growth in human society could be one of the reasons of species endangerment [11], habitat loss and fragmentation are thought to be the main reasons of biodiversity declining and populations extinction $[7,13]$. In those conditions species have two possible options - to avoid urban habitats or to accept new conditions [16]. Accepting new conditions, or synurbization sensu M. Luniak [4, 25], provides the species with some benefits such as a milder microclimate, food, places to hide etc. (as well as dangers such as heavy metal poisoning [36], stress [26] and behavioral changes [32]). Thus, this phenomenon is common for many animal species.

Bird's diversity and composition are also being affected by changes caused by urbanization [5, 10, 19, 27]. Furthermore, considering their abundance, mobility and species richness, birds are appropriate indicators of changes in ecosystems, animal communities or landscapes [14, 20, 21]. This reveals why birds are common objects in ecological studies, especially in urban habitats. From the view of avifauna, it is impossible to consider the city as a single whole, and in most research the city is considered as a complexity of different habitat types $[2,6,9]$ that makes synurbization processes easier to study in birds.

In general, habitat diversity of city urban greenery, e.g. urban parks and forests, is one of the most stable and productive in ecological meaning habitat type, which is, in fact, an "island" of wildlife in the city. It depends on origin, and can be actually a residual of native ecosystems [30]. Some authors assume that large urban parks could be a buffer for penetration of wild species into the city [37], but this question hasn't been studied enough. Nonetheless, it is known that bird diversity is high compared to other habitat types in urban parks [8, 28, 38, 40], and changes in the most diverse communities are the most informative [35], which makes urban greenery the best habitat type to study.

While spatial distribution and dynamics of bird communities in urban parks is studied well, less attention is paid to its time dynamics [24]. Bird communities are variable because of variation in species biology features and their migration status [17]. Birdhabitat relationships are unstable during the year a breeding and non-breeding periods [29]. Also migrant species contribute to general seasonal variability and birds of some species wander during the non-breeding season which means changes in their habitat preferences during the year without visible effects on species abundance on a local scale. Annual habitat preference or migration cycles affect the composition of a bird community in places with ecological consequences; it is more important to understand it in the context of possible effects of urban heat island as a part of urbanization process on birds phenological features [41].

Summarizing, information about seasonal dynamics of bird communities supplements fields of avian biology and general ecology common with topics of urban planning [24], predicting changes of bird diversity and composition caused by anthropogenic

ISSN 1996-4536 (print) • ISSN 2311-0783 (on-line) • Біологічні Студії / Studia Biologica • 2019 • Том 13/№2 • С. 79-98 
landscape transformation, which could indicate about possible future changes in other taxonomic groups and whole ecosystems, biogeographical changes and synurbization mechanisms. Also, annual dynamics, stability of community structure and dynamics of diversity level show the stability of ecosystems and primary productivity [23], according to the species-energy hypothesis [12]. This can show possible deficiency in urban greenery management - a problem that is being acutely felt in the Ukrainian cities.

The aim of this work was to reveal general tendencies of the dynamics of bird communities in urban parks, i.e. to provide a descriptive study of this phenomenon. Primarily, it was decided not to look at avian community in a discrete way, i.e. during breeding or non-breeding season, but to concern the composition dynamics as a continual process as in [32].The objectives were (1) to reveal the species composition and community structure of birds in urban greenery during throughout the year, (2) to define the time of peaks of diversity, abundance of birds and stability of the whole community, (3) to study changes in ecological (viz. trophic) and biogeographical structure of bird communities, and (4) to reveal the abundance dynamics of most common forest bird species.

\section{MATERIALS AND METHODS}

Study area. Bird surveys were conducted in Lviv city (Western Ukraine, $49^{\circ} 49^{\prime} \mathrm{N}$ $24^{\circ} 00^{\prime} \mathrm{E}$ ). Lviv is a city located on the main European watershed between the East European Plain and the North European Plain. The total population is approx. 725 thousands inhabitants and the area of administrative boundaries equals $182 \mathrm{~km}^{2}$. The area of urban greenery, according to the city council, is 4419 ha (24\% of total city area).

Study plots $(n=8)$ were chosen in order to represent the whole parks and forests on the area of the city. Linear transects (in sum, $n_{t}=20$ ) each of $500 \mathrm{~m}$ length and $100 \mathrm{~m}$ width were paved, the number of those per plot depended on the total area of model plot.

Holoskivsky cemetery is allocated in the northern suburbs, $A=80.3$ ha, $n_{t}=3$. In fact, the cemetery is a part of the Briukhovitsky forest massif ( $A=3200$ ha) - typical Roztocze forest, which has undergone strong anthropogenic transformation. Pinus sylvestris, Thuja occidentalis, Betula pendula and Acer platanoides are the most common tree species on studied transects.

Yanivsky cemetery is located in the northwestern part of the city, and it is an old cemetery. $\mathrm{A}=30 \mathrm{ha}, \mathrm{n}_{\mathrm{t}}=2$. Acer platanoides, Robinia pseudoacacia, Betula pendula, Thuja occidentalis and Fraxinus excelsior are the most common tree species.

Bilogorshcha forest is located in western suburbs near the mire and village-like part of the city. $A=195$ ha, $n_{t}=4$. Alnus glutinosa, Quercus robur, Pinus sylvestris, Betula pendula and Carpinus betulus are the most common. There are one derelict pond and a stream on that area.

Lychakivsky park and Lychakivsky cemetery are located in the eastern part of city, both are old green areas. $A=10$ ha and $A=34$ ha, respectively; $n_{t}=3$. Acer platanoides, Fraxinus excelsior, Thuja occidentalis and Pinus sylvestris are the most common.

Pohulianka forest park is adjacent to the Lychakivsky park and stretches east. $\mathrm{A}=108 \mathrm{ha}, \mathrm{n}_{\mathrm{t}}=3$. Fagus sylvatica, Carpinus betulus, Acer sp., Picea abies and Alnus glutinosa are the most common.

Stryisky park is an old park in the central part of city. $A=52$ ha, $n_{t}=3$. Acer sp., Tilia cordata, Fraxinus excelsior, Fagus sylvatica, Carpinus betulus and some exotic species, such as Salix babylonica, Ginkgo biloba and Mahonia aquifolium, form the tree community. There is one big decorative pond "Pond with swans" on the area.

ISSN 1996-4536 (print) • ISSN 2311-0783 (on-line) • Біологічні Студії / Studia Biologica • 2019 • Том 13/№2 • C. 79-98 
Osvytsky Gai park is located in the southern suburbs near the Zubra river. $A=$ 82 ha, $\mathrm{n}_{\mathrm{t}}=2$. Acer platanoides, Alnus glutinosa, Quercus robur and Fraxinus excelsior are the most common.

Bird surveys. Bird surveys were conducted on each linear transect every month during a period from December 2017 to November 2018. Linear transects method was chosen and data obtained using this method are the most representative concerning the whole community structure $[18,3]$. Birds were located at the same distance $(50 \mathrm{~m}$ on both sides from observer) in all months. Surveys were carried out during 20-30 min time period on each transect in morning hours of days without strong wind, rain, or snow. During the non-breeding season, each observed individual was registered as one, both resident and migrant birds were countered; during the breeding season, adult individuals, which probably was breeding, and juveniles were counted. This approach was used to emphasize the ecological value of each individual in the whole community, not only breeding birds. Bird species were identified by sounds or appearance; in cases of misidentification (poor information such as non-typical song or calls, quick visual observation), observations were ignored.

Private property rights were not violated during the progress of this study, entrances to all model plots are free (with exception of the Lychakiv cemetery where all tickets needed were bought).

Data analysis. Data analysis was performed using the R environment (3.5.1) [34] in RStudio (1.1.447). Packages xtable, psych, ggplot2 and dplyr were used; also own unpublished functions were used in this work for calculating Jaccard, Bray-Curtis and Simpson indices.

We used the data from each separate census $(n=12$ months $\times 20$ linear transects $=240$ censuses) for analysis. Abundance of birds was not recalculated to define the density of each species because transects of similar area $(500 \times 100 \mathrm{~m})$ were used.

Community diversity was calculated using Simpson diversity index [22]; it was chosen since it assess diversity in [0;1]-scale.

Stability between months on a defined transect was assessed using Jaccard similarity index for species presence-absence matrix and Bray-Curtis similarity index for community composition sensu lato similarity [33, 42].

Trophic preferences and zoogeographical fauna type of species became known via data of the Zoogeographical Databank of the Institute of Systematics and Ecology of Animals of SB RAS based on the works of Stegmann [39]. This databank describes the zoogeographical fauna type (in sum, 18 types; species of 6 types was presented in our data) and trophic preferences (the combination of six group: insectivorous, seed- and fruit-eaters, vegetative parts of plants eaters, raptors, insectivorous in the first part of summer and seedeater in the second, insectivorous and seedeater in the first part of summer and pure seedeater in the second; preferences described for each season: autumn, winter, spring and summer) of each species. What concerns trophic preferences, it is obviously that the sum of parts of different trophic groups in the community can be more than one, because some species can mix different diets. For example, according to the Databank, Dendrocopos major is both insectivorous and seedeater in winter. To assess the abundance of individuals of species belonging to certain ecological group or fauna type mean value was calculated ignoring cases of absence of these group representatives.

ISSN 1996-4536 (print) • ISSN 2311-0783 (on-line) • Біологічні Студії / Studia Biologica • 2019 • Том 13/№2 • С. 79-98 


\section{RESULTS AND DISCUSSION}

79 bird species were registered during one year in urban greenery in Lviv. Those taxa are listed in the Supplement according to HBW and BirdLife International taxonomy [15]. For example, the number of species that breed in parks and forests in Lviv (but only within the ecological merges) was assessed as 61 in 1994-1995 and the number of wintering species was 38; in sum, 67 species was registered in this study period by the team of ornithologists (described in PhD thesis of A. Bokotey, 1998). There are some differences in the species list caused by strong declining of some species in the city (for example, Passer domesticus and Streptopelia turtur were observed in the 1990s), rare observations of the species (Picus viridis is rare and is being under protection of the National Red List), some species was not observed during this study due to probabilistic reasons (Athene noctua and Asio otus - because special night censuses were not conducted; Anthus trivialis, Emberiza schoeniclus). Some species that were not mentioned by Bokotey were observed in this study, mainly because it concerned the periods of migrations (but other reasons, such as changes in populations or differences of study plots, can be also considered): Accipiter gentilis, Buteo buteo, Columba palumbus, Scolopax rusticola, Strix uralensis, Dendrocopos leucotos, Delichon urbicum, Hirundo rustica, Alauda arvensis, Motacilla alba, Lanius collurio, Phylloscopus trochilus, Ficedula hypoleuca, Turdus iliacus, Lophophanes cristatus, Certhia brachydactyla, Fringilla montifringilla, Acanthis flammea and Loxia curvirostra.

Species richness summarized on all transects is the lowest during the non-breeding period: it changes from 38 species registered a month in July to 30 species in August and stays on this level till the end of winter (28 in September, 30 in October, 27 in November, 31 in December, 30 in January, 27 in February). The breeding season is the period of high species richness among birds in urban greenery: 39 species were registered in March, 44 - in April, 43 - in May, 45 - in June and 38 - in July (see not summarized data on Fig. 1).

Averaged by month, all three parameters that can assess diversity level - sum of individuals of all species (which does not actually mean the diversity level), species richness and Simpson diversity index - indicate that the peak of diversity level matches with the beginning of breeding season in that latitude - end of March $\left(\Sigma n_{\text {ind. }}=40.95 \pm 17.14 \mathrm{SD}\right.$ ind./5 ha, Simpson 1-D $\left.=0.87 \pm 0.04, \mathrm{n}_{\mathrm{sp}}=12.95 \pm 2.76\right)$ and whole April $\left(\sum \mathrm{n}_{\text {ind. }}=79.1 \pm 21.58\right.$, Simpson $\left.1-\mathrm{D}=0.90 \pm 0.02, \mathrm{n}_{\mathrm{sp}}=16.40 \pm 2.78\right)$. It can be concluded that urban greenery is the more preferred biotope type by some bird species for breeding than for residence during the non-breeding season. I presume that this phenomenon is connected with some general biotope characteristics, i.e. abundance of safe places for nesting, than with food resource preferences, insofar as if the second option was true, the species richness would be saved during the whole vegetation season. Besides that, the peak of the sum of individuals can be explained by fledglings, but it is uncertain considering the data gathering methods.

Between-months, species composition stability (Fig. 2) calculated with the Jaccard index doesn't change significantly (ANOVA results for pairs Nov/Dec, Dec/Jan, Jan/Feb, Feb/Mar are $F(3,76)=0.415, p=0.743$ ) during the winter (Table 1). Significant changes of Jaccard indices were observed, again, in the beginning of the breeding season (Welch Two sample t-test for $J_{\text {Mar/Apr }}$ and $J_{\text {Apr/May }} t=-5.211$, $p$-value $=7.7 \cdot 10^{-6}$ ) and in the period between June and July (for $J_{\text {May/Jun }}$ and $J_{\text {Jun/Jul }} t=2.598$, $p$-value $=0.013$ ). 


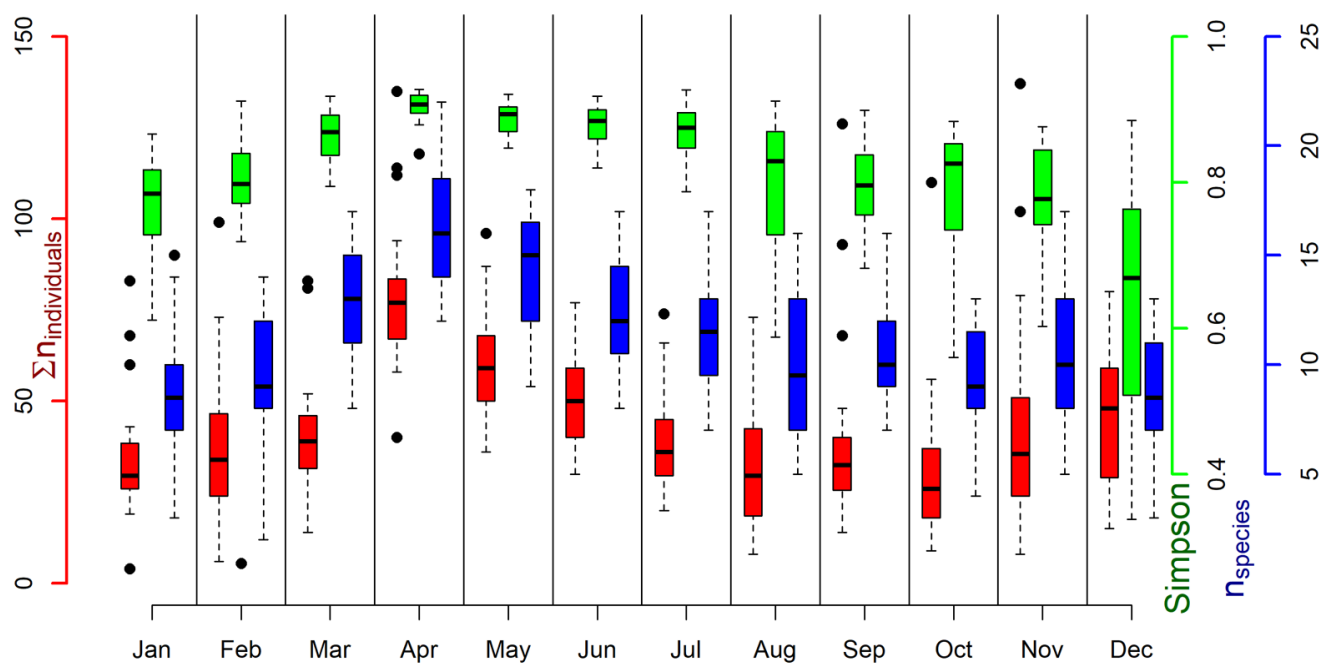

Fig. 1. Annual dynamics of all-species birds abundance, species richness and diversity assumed with Simpson index by linear transects $(A=5 \mathrm{ha})$ in urban greenery in Lviv. The interquartile range is shown as a box, the ends of the whiskers represent the minimum and maximum of all of the data, black dots are the outliers

Рис. 1. Річна динаміка чисельності птахів усіх видів, видового багатства та різноманіття (за індексом Сімпсона) птахів на лінійних трансектах (A = 5 га) у зелених зонах Львова. Міжквартильний розмах зображено як “коробку”, кінці “вусів" відповідають загальному розмаху даних, крапки позначають викиди

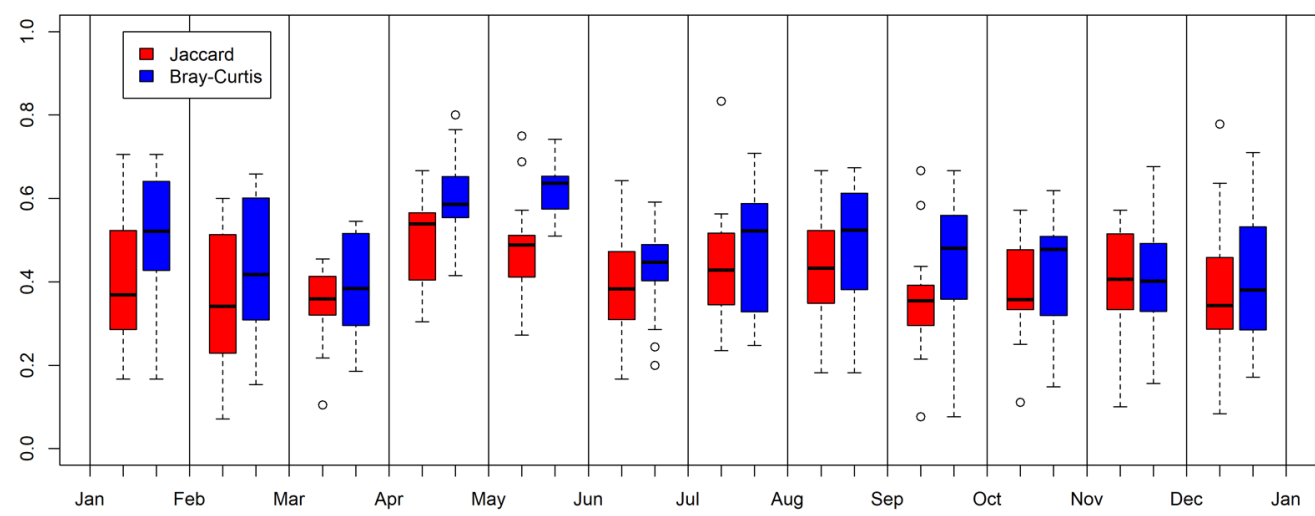

Fig. 2. Between-months, bird community stability was assessed with paired comparison similarity indices: species composition stability was assessed by Jaccard index and community structure stability was assessed by Bray-Curtis index (the higher it is, the more stable communities are between months)

Рис. 2. Стабільність угруповань птахів між місяцями оцінено за допомогою індексів подібності попарних порівнянь (бінарних мір подібності): стабільність видового складу відображає індекс Жаккара, стабільність чисельної структури угруповань відображає індекс Брея-Кьортіса (чим більші значення індексів, тим стабільніші угруповання між роками)

A similar situation was observed in community structure comparisons: significant step in community structure stability during the spring part of the non-breeding season

ISSN 1996-4536 (print) • ISSN 2311-0783 (on-line) • Біологічні Студії / Studia Biologica • 2019 • Том 13/№2 • С. 79-98 
and breeding season beginning (for $\mathrm{BC}_{\text {Mar/Apr }}$ and $\mathrm{BC}_{\text {Apr/May }} \mathrm{t}=-6.25$, $\mathrm{p}$-value $=2.95 \cdot 10^{-7}$ ) is accompanied by a descending of stability in June-July (for $\mathrm{BC}_{\text {May/Jun }}$ and $\mathrm{BC}_{\mathrm{Jun} / \mathrm{Jul}} \mathrm{t}$ $=7.52$, $p$-value $=1.32 \cdot 10^{-8}$ ). It is important that the stability value between months has two main contributing components: real variability of the community composition and probability factor (as at one linear transect one census per month was performed, all birds which were really residents at the moment were not observed). Notable, that bymonths comparisons look smooth, i.e. there are no significant dissimilarities in community composition during long period, although there does exist strong dissimilarities between community composition in long perspective.

Table 1. Mean values of the Jaccard species composition similarity index and the BrayCurtis community structure similarity index assessed for bird communities between months

Таблиця 1. Середні значення індексу подібності видового складу Жаккара та індексу подібності структури угруповань Брея-Кьортіса, обчислені для угруповань птахів між місяцями

\begin{tabular}{|c|l|l|l|l|}
\hline \multirow{2}{*}{ Months } & \multicolumn{2}{|c|}{ Jaccard index } & \multicolumn{2}{c|}{ Bray-Curtis index } \\
\hline & Mean & $\pm S D$ & Mean & \pm SD \\
\hline Jan/Feb & 0.403 & 0.146 & 0.521 & 0.145 \\
\hline Feb/Mar & 0.356 & 0.158 & 0.443 & 0.157 \\
\hline Mar/Apr & 0.347 & 0.082 & 0.394 & 0.113 \\
\hline Apr/May & 0.500 & 0.102 & 0.599 & 0.094 \\
\hline May/Jun & 0.478 & 0.110 & 0.624 & 0.063 \\
\hline Jun/Jul & 0.381 & 0.124 & 0.428 & 0.098 \\
\hline Jul/Aug & 0.436 & 0.135 & 0.472 & 0.148 \\
\hline Aug/Sep & 0.438 & 0.135 & 0.484 & 0.146 \\
\hline Sep/Oct & 0.355 & 0.124 & 0.452 & 0.145 \\
\hline Oct/Nov & 0.383 & 0.113 & 0.423 & 0.143 \\
\hline Nov/Dec & 0.399 & 0.129 & 0.415 & 0.126 \\
\hline Dec/Jan & 0.382 & 0.157 & 0.411 & 0.157 \\
\hline
\end{tabular}

Similarities between communities in different months decreases with difference in time $(\Delta \mathrm{T}=[0 ; 6]$ months). Both Jaccard index values (regression equation is $\mathrm{J}=0.603-$ $0.077 \cdot \Delta \mathrm{T}, \mathrm{p}$-value $<0.005, \mathrm{R}^{2}=0.360, \mathrm{R}^{2}{ }_{\text {adj }}=0.359$ ) and Bray-Curtis index values (regression equation is $B C=0.647-0.078 \cdot \Delta T, p$-value $<0.005, R^{2}=0.353, R_{\text {adj }}^{2}=0.359$ ) are related with months difference. Thus, it can be assumed that dynamical similarity is a function of difference in time, inflection point is approximately in $\Delta T=3\left(R^{2}\right.$ values for models with $\Delta T>3$ omitted are $R^{2}=0.493$ for Jaccard index and $R^{2}=0.500$ for Bray-Curtis index).

European zoogeographical fauna type is most common for species of birds that are breeding and residents for urban greenery in Lviv (Table 2). Absolute number of individuals of European species varies from $18.85 \pm 10.26$ ind./5 ha in October to $69.4 \pm 15.23$ ind./5 ha in April; generally, European species are the most abundant during the breeding season, but their abundance is $2-4$ times lower during the non-breeding season (August-March). Anyway, those species are the most abundant in all months.

ISSN 1996-4536 (print) • ISSN 2311-0783 (on-line) • Біологічні Студії / Studia Biologica • 2019 • Том 13/№2 • C. 79-98 
Mediterranean species are common during the non-breeding season (June-March, abundance varies from $4.50 \pm 3.32$ ind./5 ha in June to $23.20 \pm 22.75$ ind $/ / 5$ ha in December), but unreliable peak in April (from 4.60 \pm 4.62 ind./5 ha in March to $12.75 \pm 21.5 \mathrm{ind} . / 5 \mathrm{ha}$ in April, Welch Two sample $t$-test $t=-0.599$, $p$-value $=0.555$ ) shows the breeding occasions among those species. Only three Mediterranean species were registered: not common in urban greenery in Lviv Dendrocopos syriacus, Serinus serinus and extremely distributed Columba livia f. domestica. Although abundance of Mediterranean species is high, this data is unrepresentative.

Table 2. Mean abundance ( $\pm \mathbf{S D}$, ind./5 ha) and total occurrence (\%) of species of different zoogeographical types, according to Stegmann

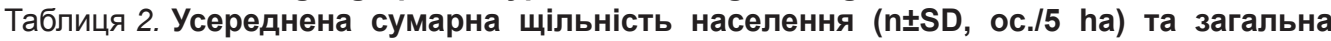
частота трапляння (\%) видів різних зоогеографічних типів за Штегманом

\begin{tabular}{|c|c|c|c|c|c|c|c|c|c|c|c|c|}
\hline \multirow{2}{*}{ Month } & \multicolumn{2}{|c|}{ SIB } & \multicolumn{2}{|c|}{ EU } & \multicolumn{2}{|c|}{ TRP } & \multicolumn{2}{|c|}{ MON } & \multicolumn{2}{|c|}{ MID } & \multicolumn{2}{|c|}{ ND } \\
\hline & $\mathrm{n} \pm \mathrm{SD}$ & $\%$ & $\mathrm{n} \pm \mathrm{SD}$ & $\%$ & $\mathrm{n} \pm \mathrm{SD}$ & $\%$ & $\mathrm{n} \pm \mathrm{SD}$ & $\%$ & $\mathrm{n} \pm \mathrm{SD}$ & $\%$ & $\mathrm{n} \pm \mathrm{SD}$ & $\%$ \\
\hline Jan & $\begin{array}{c}2.38 \\
\pm 2.07\end{array}$ & 40 & $\begin{array}{c}24.75 \\
\pm 10.29\end{array}$ & 100 & $\begin{array}{c}5.95 \\
\pm 5.55\end{array}$ & 95 & & 0 & $\begin{array}{c}20.00 \\
\pm 17.35\end{array}$ & 15 & & 0 \\
\hline Feb & $\begin{array}{c}3.18 \\
\pm 2.79\end{array}$ & 55 & $\begin{array}{c}26.85 \\
\pm 14.57\end{array}$ & 100 & $\begin{array}{c}6.63 \\
\pm 3.61\end{array}$ & 95 & & 0 & $\begin{array}{c}12.60 \\
\pm 11.15\end{array}$ & 25 & & 0 \\
\hline Mar & $\begin{array}{c}4.36 \\
\pm 3.07\end{array}$ & 55 & $\begin{array}{c}32.75 \\
\pm 14.17\end{array}$ & 100 & $\begin{array}{c}4.65 \\
\pm 3.75\end{array}$ & 100 & & 0 & $\begin{array}{c}4.60 \\
\pm 4.62\end{array}$ & 25 & & 0 \\
\hline Apr & $\begin{array}{c}5.00 \\
\pm 3.49\end{array}$ & 55 & $\begin{array}{c}69.40 \\
\pm 15.23\end{array}$ & 100 & $\begin{array}{c}4.82 \\
\pm 2.35\end{array}$ & 85 & $\begin{array}{c}2.00 \\
\pm 0.00\end{array}$ & 15 & $\begin{array}{l}12.75 \\
\pm 21.5\end{array}$ & 20 & & 0 \\
\hline May & $\begin{array}{c}4.22 \\
\pm 1.86\end{array}$ & 45 & $\begin{array}{c}53.30 \\
\pm 12.14\end{array}$ & 100 & $\begin{array}{c}4.41 \\
\pm 1.84\end{array}$ & 85 & $\begin{array}{c}2.00 \\
\pm 0.00\end{array}$ & 10 & $\begin{array}{c}7.50 \\
\pm 8.54\end{array}$ & 20 & & 0 \\
\hline Jun & $\begin{array}{c}3.43 \\
\pm 1.90\end{array}$ & 35 & $\begin{array}{c}44.00 \\
\pm 11.48\end{array}$ & 100 & $\begin{array}{c}4.71 \\
\pm 2.91\end{array}$ & 85 & $\begin{array}{c}2.00 \\
\pm 0.00\end{array}$ & 20 & $\begin{array}{c}4.50 \\
\pm 3.32\end{array}$ & 20 & & 0 \\
\hline Jul & $\begin{array}{c}2.50 \\
\pm 1.00\end{array}$ & 20 & $\begin{array}{c}31.35 \\
\pm 12.73\end{array}$ & 100 & $\begin{array}{c}6.70 \\
\pm 3.37\end{array}$ & 100 & $\begin{array}{c}1.50 \\
\pm 0.71\end{array}$ & 10 & $\begin{array}{c}3.00 \\
\pm 1.00\end{array}$ & 15 & & 0 \\
\hline Aug & $\begin{array}{c}1.25 \\
\pm 0.50\end{array}$ & 20 & $\begin{array}{c}22.00 \\
\pm 12.86\end{array}$ & 100 & $\begin{array}{c}7.15 \\
\pm 7.06\end{array}$ & 100 & 1.00 & 5 & $\begin{array}{c}11.75 \\
\pm 12.18\end{array}$ & 20 & 1.00 & 10 \\
\hline Sep & $\begin{array}{c}10.00 \\
\pm 11.53\end{array}$ & 15 & $\begin{array}{c}25.95 \\
\pm 12.66\end{array}$ & 100 & $\begin{array}{c}8.00 \\
\pm 8.31\end{array}$ & 100 & 1.00 & 5 & $\begin{array}{c}16.17 \\
\pm 23.21\end{array}$ & 30 & & 0 \\
\hline Oct & $\begin{array}{c}3.33 \\
\pm 2.24\end{array}$ & 45 & $\begin{array}{c}18.85 \\
\pm 10.26\end{array}$ & 100 & $\begin{array}{c}7.85 \\
\pm 12.78\end{array}$ & 100 & & 0 & $\begin{array}{r}13.75 \\
\pm 14.22\end{array}$ & 20 & & 0 \\
\hline Nov & $\begin{array}{c}8.40 \\
\pm 12.2\end{array}$ & 50 & $\begin{array}{c}29.45 \\
\pm 16.66\end{array}$ & 100 & $\begin{array}{c}9.79 \\
\pm 14.32\end{array}$ & 95 & & 0 & $\begin{array}{c}5.50 \\
\pm 6.14\end{array}$ & 20 & & 0 \\
\hline Dec & $\begin{array}{c}8.57 \\
\pm 13.21\end{array}$ & 35 & $\begin{array}{c}33.4 \\
\pm 17.36\end{array}$ & 100 & $\begin{array}{c}4.56 \\
\pm 3.33\end{array}$ & 90 & & 0 & $\begin{array}{c}23.20 \\
\pm 22.75\end{array}$ & 25 & & 0 \\
\hline
\end{tabular}

Comments: Codes of zoogeographical fauna types are SIB - Siberian, EU - European, TRP - Transpalearctic, MON - Mongolian, MID - Mediterranean, ND - not defined

Примітки: Коди зоогеографічних типів фауни такі: SIB - Сибірський, EU - Європейський, TRP - Tpaнспалеарктичний, MON - Монгольський, MID - Середземноморський, ND - не визначений

ISSN 1996-4536 (print) • ISSN 2311-0783 (on-line) • Біологічні Студії / Studia Biologica • 2019 • Том 13/№2 • C. 79-98 
An abundance of Siberian species is larger in the autumn and winter period than in the breeding period (10.00 \pm 11.53 ind./5 ha in September and $8.57 \pm 13.21$ ind./5 ha in December compared with $5.00 \pm 3.49$ ind./5 ha in April - the peak value in the breeding period). However, the total occurrence of Siberian species is low both in the breeding season (20-55 \%) and the non-breeding season (15-55\%).

Paying attention to occurrence distribution, European species are ubiquitous in all months, Transpalearctic species are spread too. The rarest fauna type are Mongolian (includes Phoenicurus ochruros only) and type of not defined origin (includes Streptopelia decaocto only - this species was observed in urban greenery only after the departure of migrant Columba palumbus, the species that recently became typical synanthropic in Lviv).

Invertebrate-eaters are the dominant trophic group among birds in urban greenery (see Table 3 and Fig. 3), their abundance is the largest in April (firstly, because the general birds abundance is the largest, secondly because the specific diet of the vast majority of songbirds in the period of feeding chickens). Obviously, the abundance of invertebrate-eaters is low in the winter period, only Paridae and Piciformes are common in this time. Seed-eaters are the subdominant group, the abundance of whose correlates slightly with the abundance of invertebrate-eaters $\left(r=0.364, p=6.08 \cdot 10^{-9}\right.$; Spearman rank correlation $r=0.371, p=3.05 \cdot 10^{-9}$ ).

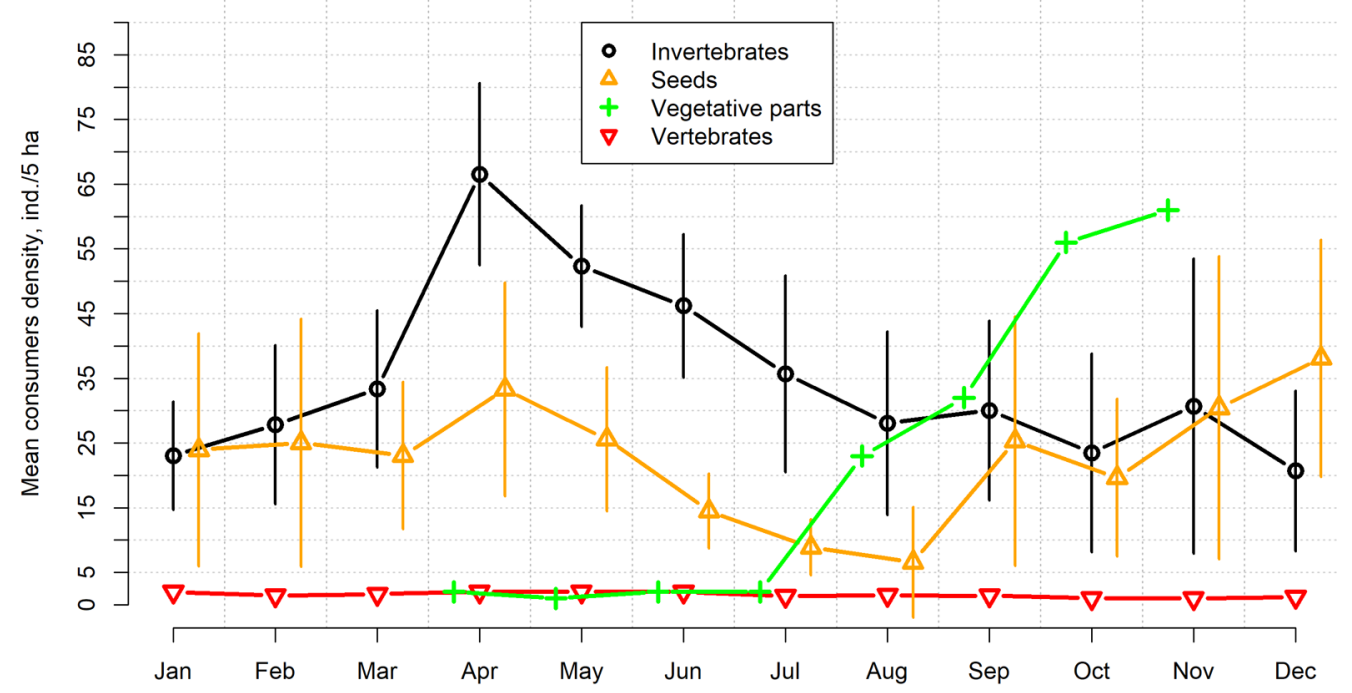

Fig. 3. Annual dynamics of abundance of birds of different trophic groups (according to food resources types)

Рис. 3. Річна динаміка чисельності птахів різних трофічних груп (за типом корму, завдяки споживанню якого задовольняються енергетичні потреби)

Vegetative parts of plants are concerned as food resources by birds in the afterbreeding season with a strong rise in autumn (abundance goes up from 2 ind./5 ha in July to 61 ind./5 ha in November, but the occurrence of species with this diet - Anas platyrchynchos - is low, just 5-10\%; Anas platyrchynchos, obviously, was registered only on plots with ponds). Abundance of vertebrate-eaters, or raptors - Accipiter nisus, Accipiter gentilis, Buteo buteo, Strix aluco, Strix uralensis (important that owls abun-

ISSN 1996-4536 (print) • ISSN 2311-0783 (on-line) • Біологічні Студії / Studia Biologica • 2019 • Том 13/№2 • C. 79-98 
dance was not the main object of this research as this requires special censuses; registrations of those two species are accidental and their occurrence is underestimated) and partial raptor Corvus corax - is low and stable through the year: 1-2 ind./5 ha, CV of means $=0.249$. Occurrence of raptors is low $-10-45 \%$ and do not depends on season $($ ANOVA F $(2,9)=1.534$, p-value $=0.267$ for groups of March-June, August-November and December-February).

The presentation of data on trophic demands structure would be more informative in relative scale, i.e. parts of individuals of defined ecological groups' species in the community, but this meets a deficiency of available classification - groups' intersection, which means that the sum of percentages of different groups would be greater than $100 \%$ calculated in a certain community. The fact that used classification was developed in the Siberian region also means that it could be inaccurate for individuals of the population present in Ukraine, thus, ecological classification of Ukrainian birds' species should be reviewed.

Table 3. Mean abundance ( $\mathbf{n} \mathbf{S D}$, ind./5 ha) and total occurrence (\%) of species of different trophic groups, by food resources type

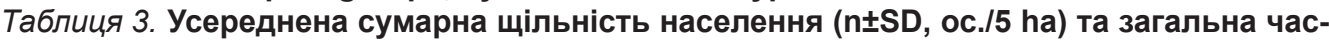
тота трапляння (\%) видів різних трофічних груп за типом корму, завдяки споживанню якого задовольняються енергетичні потреби

\begin{tabular}{|c|c|c|c|c|c|c|c|c|}
\multirow{2}{*}{ Month } & \multicolumn{2}{|c|}{ Invertebrates } & \multicolumn{2}{c|}{ Seeds } & Vegetative parts & \multicolumn{2}{c|}{ Vertebrates } \\
\cline { 2 - 9 } & $\mathrm{n} \pm \mathrm{SD}$ & $\%$ & $\mathrm{n} \pm \mathrm{SD}$ & $\%$ & $\mathrm{n} \pm \mathrm{SD}$ & $\%$ & $\mathrm{n} \pm \mathrm{SD}$ & $\%$ \\
\hline Jan & $23.05 \pm 8.34$ & 100 & $23.95 \pm 17.99$ & 100 & & 0 & $2.00 \pm 1.26$ & 30 \\
\hline Feb & $27.85 \pm 12.27$ & 100 & $25.05 \pm 19.15$ & 100 & & 0 & $1.43 \pm 0.79$ & 35 \\
\hline Mar & $33.35 \pm 12.14$ & 100 & $23.05 \pm 11.38$ & 100 & & 0 & $1.67 \pm 1$ & 45 \\
\hline Apr & $66.55 \pm 14.07$ & 100 & $33.30 \pm 16.53$ & 100 & 2.00 & 5 & $2.00 \pm 0.00$ & 35 \\
\hline May & $52.35 \pm 9.35$ & 100 & $25.60 \pm 11.12$ & 100 & 1.00 & 5 & $2.00 \pm 0.00$ & 35 \\
\hline Jun & $46.20 \pm 11.09$ & 100 & $14.50 \pm 5.81$ & 100 & 2.00 & 5 & $2.00 \pm 0.00$ & 15 \\
\hline Jul & $35.70 \pm 15.19$ & 100 & $8.89 \pm 4.31$ & 95 & 2.00 & 5 & $1.33 \pm 0.58$ & 15 \\
\hline Aug & $28.05 \pm 14.17$ & 100 & $6.60 \pm 8.54$ & 75 & $23.00 \pm 1.41$ & 10 & $1.50 \pm 0.71$ & 10 \\
\hline Sep & $30.05 \pm 13.88$ & 100 & $25.30 \pm 19.27$ & 100 & 32.00 & 5 & $1.40 \pm 0.89$ & 25 \\
\hline Oct & $23.50 \pm 15.35$ & 100 & $19.65 \pm 12.19$ & 100 & 56.00 & 5 & $1.00 \pm 0.00$ & 20 \\
\hline Nov & $30.70 \pm 22.77$ & 100 & $30.45 \pm 23.42$ & 100 & 61.00 & 5 & $1.00 \pm 0.00$ & 20 \\
\hline Dec & $20.70 \pm 12.41$ & 100 & $38.10 \pm 18.30$ & 100 & & 0 & $1.20 \pm 0.45$ & 25 \\
\hline
\end{tabular}

Seasons classified as winter - December, January and February, Spring - March, Breeding - April, May, June and July, autumn - August, September, October and November, affects densities of several species, as results of ANOVA tests show.

Thus, season affects (in terms of ANOVA results) individuals density in common migrant songbirds species such as Fringilla coelebs $(F(3,236)=88.57$, p-value $<0.001)$, Erithacus rubecula $(F(3,236)=59.16$, p-value $<0.001)$, Sylvia atricapilla $(F(3,236)=53.36$, p-value $<0.001)$, Phylloscopus collybita $(F(3,236)=38.44$, p-value $<0.001)$, Columba

ISSN 1996-4536 (print) • ISSN 2311-0783 (on-line) • Біологічні Студії / Studia Biologica • 2019 • Том 13/№2 • С. 79-98 
palumbus $(\mathrm{F}(3,236)=30.11$, p-value $<0.001)$, Turdus philomelos $(\mathrm{F}(3,236)=28.58$, p-value $<0.001)$, Ficedula albicollis $(F(3,236)=20.24$, p-value $<0.001)$, Sturnus vulgaris $(F(3,236)=12.28$, p-value $<0.001)$, Phylloscopus sibilatrix $(F(3,236)=11.43$, p-value $<0.001)$, Muscicapa striata $(F(3,236)=8.76$, p-value $<0.001)$, Phoenicurus ochruros $(F(3,236)=7.06$, p-value $<0.001)$, Oriolus oriolus $(F(3,236)=5.83$, p-value $<0.001)$, Sylvia curruca $(F(3,236)=4.31$, p-value $=0.006)$, Serinus serinus $(F(3$, $236)=3.89$, p-value $=0.010)$ and Phylloscopus trochilus $(\mathrm{F}(3,236)=3.82$, $\mathrm{p}$-value $=0.011)$ (see Fig. 4).

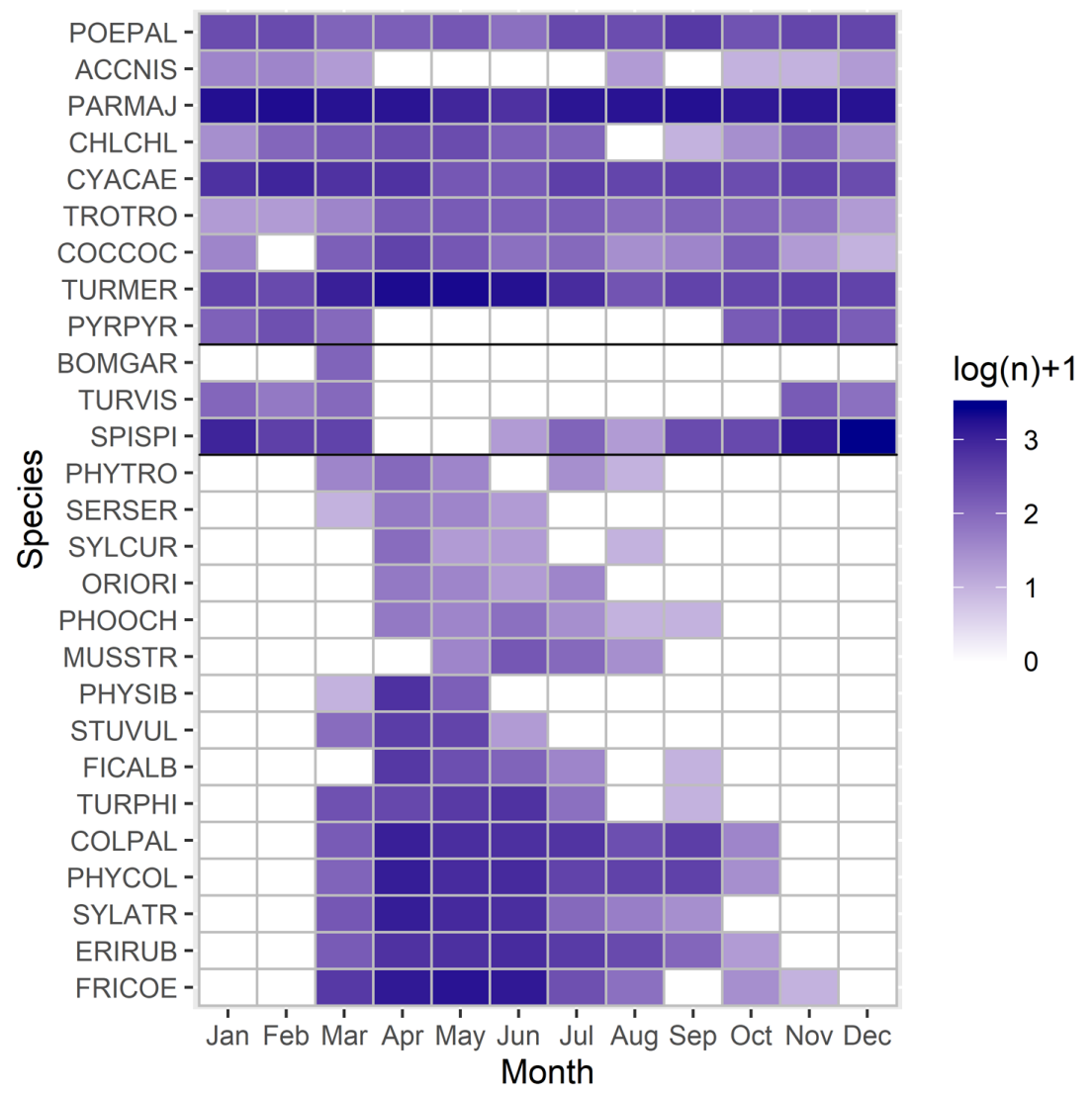

Fig. 4. Annual dynamics of $\left(\log _{10}+1\right)$-modified [1] averaged abundance (ind. $\left./ \mathrm{km}^{2}\right)$ of different birds species which show a dependence on season

Рис. 4. Річна динаміка модифрікованої [1] усередненої чисельності (ос./км²) видів птахів, що виявляють залежність чисельності від сезону

The same is observed with common wintering species: Spinus spinus $(F(3,236)=$ 13.46, p-value < 0.001), Turdus viscivorus $(\mathrm{F}(3,236)=7.61$, p-value $<0.001)$, Bombycilla garrulus $(F(3,236)=5.36$, $p$-value $=0.0013$; unreliable result due to this species observation is singleton), Pyrrhula pyrrhula $(F(3,236)=5.33$, p-value $=0.0014)$.

Variability of some resident species abundances can be explained by season too (this wording is unsure for ANOVA method): Turdus merula $(F(3,236)=67.31$, p-value $<0.001)$, Coccothraustes coccothraustes $(F(3,236)=10.62$, p-value $<0.001)$, 
Troglodytes troglodytes $(\mathrm{F}(3,236)=10.22$, p-value $<0.001)$, Cyanistes caeruleus $(\mathrm{F}(3$, $236)=9.05$, p-value $<0.001)$, Chloris chloris $(\mathrm{F}(3,236)=7.01$, p-value $<0.001)$ etc .

For some species this variability can be explained by changing biotopes preferences, which should be proven by the results of special research. For example, the abundance of Turdus merula in April is $10.4 \pm 4.28$ ind./ 5 ha and $11.1 \pm 4.18$ ind./ 5 ha in May, but 2.69 \pm 2.06 in December; moreover, the occurrence of this species is $100 \%$ during the breeding season, but it is $50-60 \%$ in winter. Further statistical analysis is needed to make specific conclusions about common synurbanized forest bird species ecology dynamics.

\section{CONCLUSIONS}

79 birds' species were found to occur in urban greenery in Lviv throughout the year.

The highest diversity level and abundance of birds is observed during the breeding period, especially in April, when many species begin breeding. A slight peak of abundance is observed during winter season, inasmuch as urban habitats afford special conditions, such as food resources and softer weather, to outlive this period successfully. Nonetheless, in this particular case the diversity of birds in urban greenery declines during the non-breeding season. This could mean that urban greenery is the more preferred biotope type by some bird species for breeding than for residence during the non-breeding season.

Between-months, community stability among birds in urban greenery is higher both for presence-absence species composition and numerical structure during the breeding season that shows that most of the birds are highly attached to their nesting sites, especially in April, May and June. Similarities between communities in different months decrease with difference in time.

European bird species make a nucleus of community structures in all months. Siberian, Mediterranean and Transpalearctic species are also common in urban greenery. Their role becomes more important during the non-breeding season, but separately by types all of them subdominate compared with European.

Invertebrates are the main food resources for most individual birds. Their role is especially important for birds of urban greenery while feeding nestlings; naturally, in cold months, the majority of birds predominantly use other food resources, particularly seeds. The abundance of raptor species is low and stable in all months.

Season can be considered as a factor related with the abundance of several species. Thus, bird species that are typical for urban greenery in Lviv can de divided into three groups. First, there are songbirds species that only breed in examined sites, such as Fringilla coelebs, Erithacus rubecula, Sylvia atricapilla, Phylloscopus collybita, Columba palumbus, Turdus philomelos, Ficedula albicollis, Sturnus vulgaris, Phylloscopus sibilatrix, Muscicapa striata, Phoenicurus ochruros, Oriolus oriolus, Sylvia curruca, Serinus serinus and Phylloscopus trochilus. Second group is wintering species that are not typically breed in those locations: Spinus spinus, Turdus viscivorus, Bombycilla garrulus, Pyrrhula pyrrhula. Third are species whose abundance varies as response on season, which can indicate unrevealed spatial-seasonal dynamics in terms of different habitat types. Those species are might be resident in Lviv: Turdus merula, Coccothraustes coccothraustes, Troglodytes troglodytes, Cyanistes caeruleus, Chloris chloris, Parus major, Poecile palustris. Spatial dynamics of different populations and subpopulations of those species needs special study.

ISSN 1996-4536 (print) • ISSN 2311-0783 (on-line) • Біологічні Студії / Studia Biologica • 2019 • Том 13/№2 • С. 79-98 


\section{ACKNOWLEDGEMENTS}

Author is grateful to his father Dmytro and wants to dedicate this article to the blessed memory of him.

The support of supervisor Ihor Shydlovskyy was considerable for writing this paper. Financial support for this research was provided by the Dovkolabotanika community.

The critical reviews of Tomasz Mazgajski and anonymous peer reviewer were helpful in defining mistakes and inaccuracies in this work.

Special thanks for Benjamin Jackson for eliminating grammatical and stylistic mistakes, and Nadya Chepelevska and Vitalii Goncharenko for help with defining species composition of trees on model plots.

1. Anderson M.J., Ellingsen K.E., McArdle B.H. Multivariate dispersion as a measure of beta diversity. Ecology Letters, 2006; 9(6): 683-693.

[DOI: https://doi.org/10.1111/j.1461-0248.2006.00926.x]

2. Biaduń $W$. Winter avifauna of Lublin - species composition, distribution and numbers. Berkut, 2005; 14(1): 1-23.

3. Bibby C.J., Burgess N.D., Hill D.A., Mustoe S. Bird census techniques. $2^{\text {nd }}$ Ed. London, UK: Academy Press, 2000. 300 p.

4. Birnie-Gauvin K., Peiman K.S., Gallagher A.J., de Bruijn R., Cooke S.J. Sublethal consequences of urban life for wild vertebrates. Environ. Rev., 2016; 24(4): 416-425.

[DOI: https://doi.org/10.1139/er-2016-0029]

5. Blair R.B., Johnson E.M. Suburban habitats and their role for birds in the urban-rural habitat network: points of local invasion and extinction? Landscape Ecol, 2008; 23(10): 1157-1169. [DOI: https://doi.org/10.1007/s10980-008-9267-y]

6. Bokotey A.A. The structure of methodological approaches to study the bird population in urban landscapes (on the example of L'viv sity). In: IBA Program. Bird Censuses: Approaches, Methods, Results. Lviv; Kyiv: Ukrainian Socety for the Protection of Birds, 1997. P. 58-62. (In Ukrainian)

7. Brooks T.M., Mittermeier R.A., Mittermeier C.G., Fonseca G.A.B.D., Rylands A.B., Konstant W.R., Flick P., Pilgrim J., Oldfield S., Magin G., Hilton-Taylor C. Habitat Loss and Extinction in the Hotspots of Biodiversity. Conservation Biology, 2002; 16(4): 909-923.

[DOI: https://doi.org/10.1046/j.1523-1739.2002.00530.x].

8. Carbó-Ramírez P., Zuria I. The value of small urban greenspaces for birds in a Mexican city. Landscape and Urban Planning, 2011; 100(3): 213-222.

[DOI: https://doi.org/10.1016/j.landurbplan.2010.12.008]

9. Ciach M., Fröhlich A. Habitat type, food resources, noise and light pollution explain the species composition, abundance and stability of a winter bird assemblage in an urban environment. Urban Ecosystems, 2017; 20(3): 547-559.

[DOI: https://doi.org/10.1007/s11252-016-0613-6]

10. Ciach $M$. The winter bird community of rural areas in the proximity of cities: Low density and rapid decrease in diversity. Pol. J. Ecol., 2012; 60(1): 193-199.

11. Czech B., Krausman P.R., Devers P.K. Economic associations among causes of species endangerment in the United States. BioScience, 2000; 50(7): 593-601.

[DOI: https://doi.org/10.1641/0006-3568(2000)050[0593:EAACOS]2.0.CO;2].

12. Evans K.L., Warren P.H., Gaston K.J. Species-energy relationships at the macroecological scale: a review of the mechanisms. Biol. Rev., 2005; 80(1): 1-25.

[DOI: https://doi.org/10.1017/S1464793104006517]

13. Fahrig $L$. Relative effects of habitat loss and fragmentation on population extinction. The Journal of Wildlife Management, 1997; 61(3): 603-610.

[DOI: https://doi.org/10.2307/3802168]

ISSN 1996-4536 (print) • ISSN 2311-0783 (on-line) • Біологічні Студії / Studia Biologica • 2019 • Том 13/№2 • C. 79-98 
14. Furness R.W., Greenwood J.J.D. Birds as Monitors of Environmental Change. Dordrecht: Springer Science \& Business Media, 2013. 356 p.

[DOI: https://doi.org/10.1007/978-94-015-1322-7]

15. HBW and BirdLife International. Handbook of the Birds of the World and BirdLife International digital checklist of the birds of the world. Version 3 :

http://datazone.birdlife.org/species/taxonomy (access from 11.07.2019)

16. Isaksson C. Impact of urbanization on birds. In: Tietze D.T. (Ed.) Bird species: how they arise, modify and vanish, fascinating life sciences. Cham: Springer International Publishing, 2018: 235-257.

[DOI: https://doi.org/10.1007/978-3-319-91689-7_13]

17. Ivliev V.G., Ravkin Y.S., Bogomolova I.N. Seasonal and annual dynamics of birds population in Kazan suburbs. Russian Journal of Applied Ecology, 2016; 4: 8-16. (In Russian)

18. Järvinen O., Väisänen R.A. Finnish line transect censuses. Ornis Fennica, 1976; 53: 115-118.

19. Jokimäki J., Clergeau P., Kaisanlahti-Jokimäki M.-L. Winter bird communities in urban habitats: a comparative study between central and northern Europe. Journal of Biogeography, 2002; 29(1): 69-79.

20. Kati V., Devillers P., Dufrêne M., Legakis A., Vokou D., Lebrun P. Testing the value of six taxonomic groups as biodiversity indicators at a local scale. Conservation Biology, 2004; 18(3): 667-675.

[DOI: https://doi.org/10.1111/j.1523-1739.2004.00465.x]

21. Koskimies P. Birds as a tool in environmental monitoring. Annales Zoologici Fennici, 1989; 26(3): 153-166.

22. Legendre P., Legendre L. Numerical ecology. 2nd Ed. Amsterdam, New York: Elsevier, 1998. $852 \mathrm{p}$.

23. Leveau L.M., Isla F.I., Bellocq M.I. Predicting the seasonal dynamics of bird communities along an urban-rural gradient using NDVI. Landscape and Urban Planning, 2018; 177 103-113.

[DOI: https://doi.org/10.1016/j.landurbplan.2018.04.007]

24. Leveau L.M., Leveau C.M. Does urbanization affect the seasonal dynamics of bird communities in urban parks? Urban Ecosyst, 2016; 19(2): 631-647.

[DOI: https://doi.org/10.1007/s11252-016-0525-5]

25. Luniak M. Synurbization - adaptation of animal wildlife to urban development. In: Proceedings of the 4th International Symposium on Urban Wildlife Conservation. Tucson: The University of Arizona, 2004: 50-55.

26. Meillère A., Brischoux F., Bustamante P., Michaud B., Parenteau C., Marciau C., Angelier F. Corticosterone levels in relation to trace element contamination along an urbanization gradient in the common blackbird (Turdus merula). Science of The Total Environment, 2016; 566-567: 93-101.

[DOI: https://doi.org/10.1016/j.scitotenv.2016.05.014]

27. Møller A.P., Diaz M., Flensted-Jensen E., Grim T., Ibáñez-Álamo J.D., Jokimäki J., Mänd R., Markó G., Tryjanowski P. High urban population density of birds reflects their timing of urbanization.Oecologia, 2012; 170(3): 867-875.

[DOI: https://doi.org/10.1007/s00442-012-2355-3]

28. Morelli F., Mikula P., Benedetti Y., Bussière R., Tryjanowski P. Cemeteries support avian diversity likewise urban parks in European cities: Assessing taxonomic, evolutionary and functional diversity. Urban Forestry \& Urban Greening, 2018; 36: 90-99.

[DOI: https://doi.org/10.1016/j.ufug.2018.10.011]

29. Murgui E. Seasonality and nestedness of bird communities in urban parks in Valencia, Spain. Ecography, 2010; 33(5): 979-984.

[DOI: https://doi.org/10.1111/j.1600-0587.2010.05816.x]

30. Nagendra H., Gopal D. Tree diversity, distribution, history and change in urban parks: studies in Bangalore, India. Urban Ecosystems, 2011; 14(2): 211-223.

[DOI: https://doi.org/10.1007/s11252-010-0148-1]

ISSN 1996-4536 (print) • ISSN 2311-0783 (on-line) • Біологічні Студії / Studia Biologica • 2019 • Том 13/№2 • C. 79-98 
31. Nemeth E., Brumm H. Blackbirds sing higher-pitched songs in cities: adaptation to habitat acoustics or side-effect of urbanization? Anim. Behav., 2009; 78: 637-641.

[DOI: https://doi.org/doi:10.1016/j.anbehav.2009.06.016]

32. Pfeifer R., Stadler J., Roland $P$. Is the seasonal variation of abundance and species richness in birds explained by energy availability? Acta ornithologica, 2018; 52(2): 167-178.

[DOI: https://doi.org/10.3161/00016454AO2017.52.2.005]

33. Quinn G.P., Keough M.J.Experimental design and data analysis for biologists. Cambridge: Cambridge University Press, 2002. 538 p.

34. R Core Team. R: A language and environment for statistical computing: https://www.R-project.org/

35. Rotenberry J.T., Fitzner R.E., Rickard W.H. Seasonal variation in avian community structure: differences in mechanisms regulating diversity. Auk, 1979; 96: 499-505.

36. Scheifler R., Coeurdassier M., Morilhat C., Bernard N., Faivre B., Flicoteaux P., Giraudoux P., Noël M., Piotte P., Rieffel D., de Vaufleury A., Badot P.-M. Lead concentrations in feathers and blood of common blackbirds (Turdus merula) and in earthworms inhabiting unpolluted and moderately polluted urban areas. Science of The Total Environment, 2006; 371(1-3): 197-205.

[DOI: https://doi.org/10.1016/j.scitotenv.2006.09.011]

37. Senyk M., Hornyak M. Contemporary changes in the ornithofauna of Lviv city. Berkut, 2003; 12(1-2): 9-13. (In Ukrainian)

38. Shih W.-Y. Bird diversity of greenspaces in the densely developed city centre of Taipei. Urban Ecosyst, 2017; 21(2): 379-393.

[DOI: https://doi.org/10.1007/s11252-017-0720-z]

39. Stegmann $B$. Principes généraux des subdivisions ornithogéographiques de la région Paléarctique. Moscou: Edition de l'Académie sed Sciences de l'URSS, 1938. 158 p.

40. Strohbach M.W., Lerman S.B., Warren P.S. Are small greening areas enhancing bird diversity? Insights from community-driven greening projects in Boston. Landscape and Urban Planning, 2013; 114: 69-79.

[DOI: https://doi.org/10.1016/j.landurbplan.2013.02.007]

41. Tryjanowski P., Sparks T.H., Kuźniak S., Czechowski P., Jerzak L. Bird migration advances more strongly in urban environments. PLoS ONE, 2013; 8(5): 6 p.

[DOI: https://doi.org/10.1371/journal.pone.0063482]

42. Wolda H. Similarity indices, sample size and diversity. Oecologia, 1981; 50(3): 296-302.

\title{
РІЧНА ДИНАМІКА УГРУПОВАНЬ ПТАХІВ У ЗЕЛЕНИХ ЗОНАХ ЛЬВОВА: ПОПЕРЕДНІЙ АНАЛІЗ ВАРІАБЕЛЬНОСТІ РІЗНОМАНІТТЯ І СТРУКТУРИ
}

\author{
О. Дубовик \\ Львівський національний університет імені Івана Франка \\ вул. Грушевського, 4, Львів 79005, Україна \\ e-mail: oadubovyk@gmail.com
}

Проаналізовано видовий і чисельний склад угруповань птахів у зелених зонах Львова за результатами щомісячних обліків, проведених на 20 трансектах на восьми модельних ділянках. Протягом періоду досліджень зареєстровано 79 видів птахів, що належать до восьми рядів. Різноманіття птахів, оцінене за кількістю видів та індексом Сімпсона, варіює протягом року і $є$ найвищим у гніздовий сезон. Аналогічно, щільність птахів найвища у гніздовий сезон, проте менший пік чисельності спостерігається і в зимовий період. Це вказує на те, що біотопні преференції окремих видів птахів до зелених зон особливо виражені лише у гніздовий сезон, тоді як

ISSN 1996-4536 (print) • ISSN 2311-0783 (on-line) • Біологічні Студії / Studia Biologica • 2019 • Том 13/№2 • С. 79-98 
у позагніздовий більшість птахів залишаються осілими в межах міста, проте переміщуються в біотопи інших типів. Проаналізовано міжмісячну стабільність видового складу угруповань птахів (за індексом Жаккара) та чисельного їхнього складу (за індексом Брея-Кьортіса): угруповання найбільш стабільні у гніздовий період, оскільки птахи в переважній більшості прив'язані до гніздових ділянок. За зоогеографічним поділом, європейські види птахів домінують у всі місяці. Сибірські, транспалеарктичні та середземноморські види також відіграють значну роль у фрормуванні структури угруповань. Основним типом корму, завдяки споживанню якого компенсуються енергетичні витрати птахів у гніздовий сезон, є безхребетні, що вказує на особливу роль птахів у контролі чисельності безхребетних в урбанізованих середовищах. У позагніздовий сезон важливим компонентом кормової бази птахів $€$ також насіння рослин. Варіабельність чисельності багатьох видів пов'язана зі сезоном. Виділено три основні групи таких видів: гніздові мігранти (переважно співочі птахи, зокрема, Fringilla coelebs, Erithacus rubecula, Sylvia atricapilla, Phylloscopus collybita тощо, також Columba palumbus), зимуючі мігранти (Spinus spinus, Turdus viscivorus, Bombycilla garrulus, Pyrrhula pyrrhula) і типові осілі, чисельність яких значно варіює за сезонами (Turdus merula, Coccothraustes coccothraustes, Troglodytes troglodytes, Cyanistes caeruleus тощо). Останні, ймовірно, в позагніздовий період дифундують в інші біотопи міста.

Ключові слова: сезонна варіабельність, міські екосистеми, синантропні види, видовий склад населення птахів, міські насадження, угруповання птахів

Одержано: 26.07.2019

ISSN 1996-4536 (print) • ISSN 2311-0783 (on-line) • Біологічні Студії / Studia Biologica • 2019 • Том 13/№2 • С. 79-98 


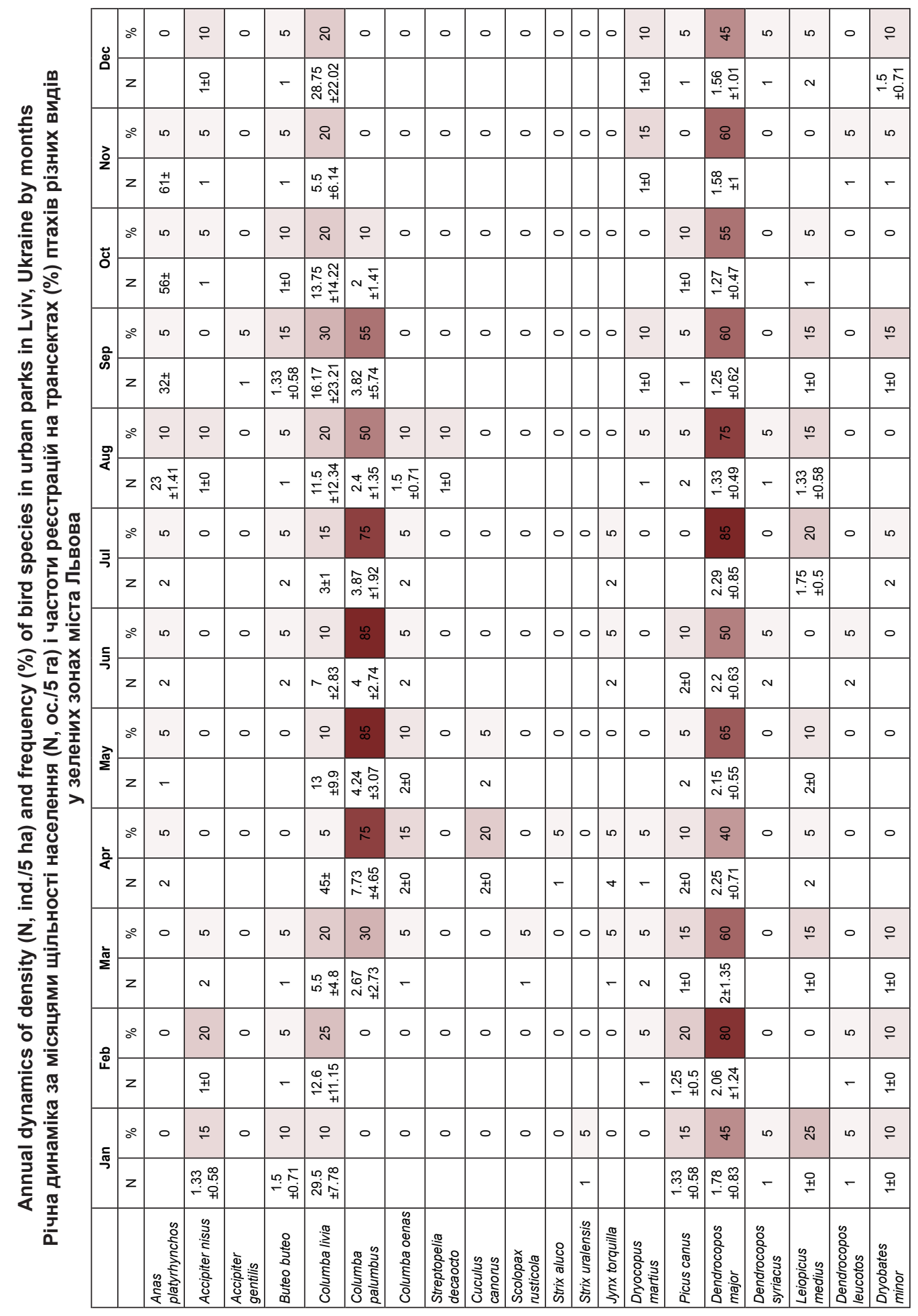




\begin{tabular}{|c|c|c|c|c|c|c|c|c|c|c|c|c|c|c|c|c|c|c|c|c|c|c|c|c|}
\hline \multirow{2}{*}{ Фे } & $\therefore$ & 0 & 0 & 0 & 0 & 0 & 0 & 0 & $\stackrel{\mathfrak{R}}{\stackrel{2}{2}}$ & g & is & is & 은 & 음 & 우 & 0 & 0 & 0 & 0 & 0 & 0 & 0 & 0 & 0 \\
\hline & $z$ & & & & & & & & $\underset{\sim}{\infty} \underset{\sim}{\infty} \underset{+}{F}$ & 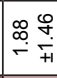 & $\nabla$ & $\simeq$ & 요 & 占 & 표 & & & & & & & & & \\
\hline \multirow[b]{2}{*}{ 20 } & $\therefore$ & 0 & 0 & 0 & 0 & 0 & 0 & 0 & $\ddot{8}$ & $\stackrel{m}{m}$ & 0 & $\stackrel{2}{2}$ & 0 & 으 & চ্ & 0 & 0 & 0 & 0 & 0 & 0 & 0 & 0 & 0 \\
\hline & $z$ & & & & & & & & 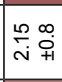 & 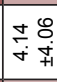 & & \begin{tabular}{|cc}
0 & 9 \\
0 & 0 \\
0 & 0 \\
0 & +1
\end{tabular} & & 위 & 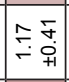 & & & & & & & & & \\
\hline \multirow{2}{*}{$\overline{\mathrm{o}}$} & $\therefore$ & 0 & 0 & 0 & 0 & 0 & 0 & 。 & i & ల్ల & 0 & ம & ○ & م & q & 0 & 0 & 0 & 0 & 0 & 0 & 0 & 0 & $\stackrel{\circ}{\circ}$ \\
\hline & $z$ & & & & & & & & 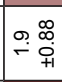 & 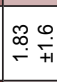 & & $m$ & - & - & 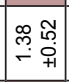 & & & & & & & & & 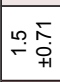 \\
\hline \multirow[b]{2}{*}{ ڤ্̀ } & $\therefore$ & $\circ$ & 0 & 0 & 0 & 0 & 0 & 0 & $\stackrel{\infty}{\infty}$ & 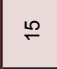 & 0 & م & 0 & $\stackrel{\circ}{\circ}$ & is & 0 & 0 & 웅 & 0 & 0 & 0 & 0 & 0 & 吕 \\
\hline & $z$ & & & & & & & & 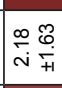 & $\stackrel{ }{\stackrel{1}{1}}$ & & $\infty$ & & 위 & 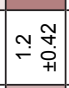 & & & 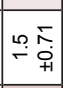 & & & & & & 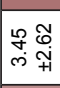 \\
\hline \multirow[b]{2}{*}{ 岁 } & $\therefore$ & $\circ$ & 0 & 0 & 0 & 0 & 0 & 0 & $\stackrel{2}{2}$ & 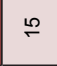 & 0 & $\circ$ & 0 & 0 & ळ & 0 & $\circ$ & i & 0 & 10 & 0 & م & 0 & \& \\
\hline & $z$ & & & & & & & & $\begin{array}{cc} & \infty \\
0 & \infty \\
\sim & 0 \\
+1\end{array}$ & \begin{tabular}{|l|l}
\multirow{2}{*}{} \\
îj \\
\end{tabular} & & & & & 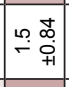 & & & 岕 & & - & & - & & 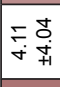 \\
\hline \multirow[b]{2}{*}{ इ } & $\therefore$ & $\circ$ & 0 & 0 & 0 & 0 & $\circ$ & 0 & $\stackrel{8}{\circ}$ & 0 & 0 & 0 & 0 & $\stackrel{\circ}{\circ}$ & $\stackrel{\mathscr{m}}{\circ}$ & 0 & م & $\stackrel{\circ}{\llcorner}$ & 0 & 0 & 0 & n & $\circ$ & 吕 \\
\hline & $z$ & & & & & & 扸 & & 웟 & & & & & 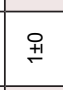 & 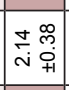 & & N & 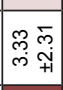 & & & & $m$ & & $\stackrel{\infty}{\infty} \underset{\infty}{\infty} \frac{\infty}{+1}$ \\
\hline \multirow{2}{*}{ 气 } & $\therefore$ & n & 0 & 0 & م & $\div$ & م & เ & $\stackrel{n}{\leftarrow}$ & ๑ & 0 & $\circ$ & ص & 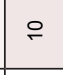 & ஜ & 0 & 0 & $\stackrel{\llcorner}{\curvearrowright}$ & o & ம & 0 & 0 & 0 & 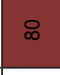 \\
\hline & $z$ & $\sim$ & & & $\sim$ & 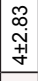 & $\sim$ & $N$ & 워 & $\sim$ & & & $\sim$ & 에 & IN & & & $\begin{array}{ll}\infty & \widehat{\sim} \\
\dot{\sim} & +1\end{array}$ & $\sim$ & $N$ & & & & 둭 \\
\hline \multirow{2}{*}{$\frac{\pi}{2}$} & $\therefore$ & 0 & ద & 0 & 0 & in & $\circ$ & in & 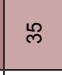 & 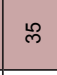 & 0 & 0 & 0 & $\circ$ & q & 0 & ద & $\%$ & $\infty$ & ( & 0 & $\stackrel{\circ}{\circ}$ & $\stackrel{\llcorner}{\sim}$ & $\stackrel{2}{\sim}$ \\
\hline & z & & $\sim$ & & & N & 古 & 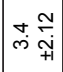 & $\stackrel{P}{N}$ & I & & & & & 웜 & & $\sim$ & 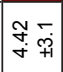 & $\sim$ & $\sim$ & & I & $\stackrel{\infty}{\sim} \underset{+}{-}$ & ஸ \\
\hline \multirow{2}{*}{$\frac{a}{4}$} & $\therefore$ & 0 & 0 & 0 & 0 & 0 & $\stackrel{\llcorner}{\llcorner}$ & is & 8 & $\stackrel{\sim}{\sim}$ & 0 & 0 & م & is & q & 0 & 0 & & 0 & $\stackrel{2}{\sim}$ & ம & $\stackrel{\sim}{N}$ & 8 & ळ \\
\hline & $z$ & & & & & & 워N & 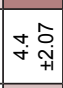 & N & 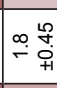 & & & $\sim$ & $\sim$ & ㅇN & & & 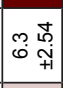 & & 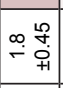 & N & 辣 & $\mid$\begin{tabular}{c}
\multirow{2}{\sim}{$\underset{\sim}{\sim}$} \\
\multirow{+}{*}{}
\end{tabular} & 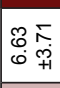 \\
\hline \multirow{2}{*}{$\stackrel{\text { In }}{\Sigma}$} & $\therefore$ & $\circ$ & 0 & 음 & 0 & 0 & 0 & $\stackrel{2}{N}$ & 8 & $\ddot{m}$ & 。 & 0 & م & ๑ & ㄱ. & 우 & $\circ$ & ని & 0 & 0 & 0 & เ & م & ᄋ్ల \\
\hline & $z$ & & & ז & & & & 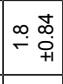 & $\stackrel{\infty}{\infty} \underset{\sim}{\infty}$ & 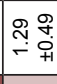 & & & - & $\sim$ & 윈 & $\begin{array}{l}0 \\
0 \\
0 \\
01 \\
01\end{array}$ & & 馆 & & & & $\sigma$ & - & กี \\
\hline \multirow{2}{*}{ 。ํㄴ } & $\therefore$ & 0 & 0 & 0 & 0 & 0 & 0 & ○ & R & $\stackrel{\sim}{\sim}$ & 。 & 웅 & م & $\stackrel{5}{\circ}$ & 으 & 0 & 0 & 0 & 0 & 0 & 0 & 0 & 0 & 0 \\
\hline & $z$ & & & & & & & & $\begin{array}{l}\infty \\
\infty \\
\sim \\
\sim \\
+1\end{array}$ & 正 & & 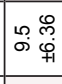 & N & 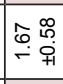 & 위 & & & & & & & & & \\
\hline & $\therefore$ & 0 & 0 & 0 & 0 & 0 & 0 & 0 & 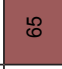 & ๙ి & 0 & n & 0 & $\stackrel{2}{\leftarrow}$ & 으 & $\circ$ & 0 & $\circ$ & 0 & 0 & 0 & 0 & 0 & 0 \\
\hline & $z$ & & & & & & & & $\stackrel{\substack{0 \\
+}}{\stackrel{0}{+}}$ & $\stackrel{1}{\stackrel{1}{1}}$ & & 0 & & 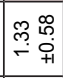 & 위 & & & & & & & & & \\
\hline & & 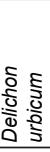 & 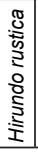 & 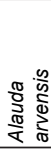 & 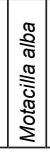 & 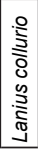 & 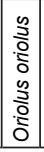 & 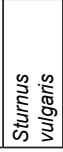 & 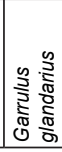 & 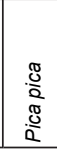 & 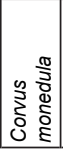 & 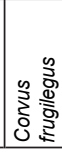 & 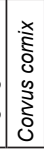 & 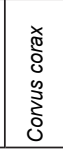 & 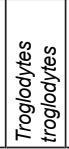 & 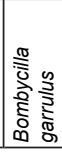 & 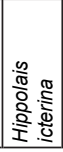 & 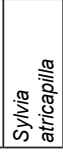 & 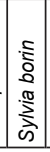 & 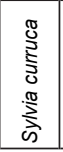 & 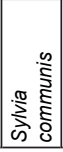 & 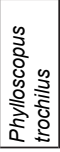 & 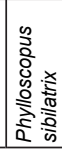 & 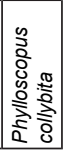 \\
\hline
\end{tabular}




\begin{tabular}{|c|c|c|c|c|c|c|c|c|c|c|c|c|c|c|c|c|c|c|c|c|c|c|}
\hline \multirow[b]{2}{*}{ Ф } & $\circ$ & 0 & 0 & 0 & 우 & 0 & 0 & 0 & 0 & م & $\ddot{\bullet}$ & 0 & $\stackrel{\mathscr{N}}{\sim}$ & 0 & م & 吕 & م & 8 & 0 & จิ & & \\
\hline & $z$ & & & & 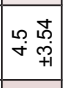 & & & & & 0 & 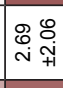 & & \begin{tabular}{rr}
0 & 0 \\
\hdashline & 0 \\
\hdashline & 0 \\
+
\end{tabular} & & 0 & 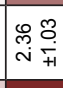 & N & 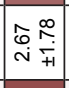 & & $\begin{array}{l}\tilde{N} \\
0 \\
0 \\
01 \\
0\end{array}$ & 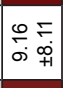 & 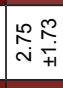 \\
\hline \multirow{2}{*}{ z } & $\therefore$ & 0 & 0 & 0 & $\stackrel{2}{2}$ & 0 & 0 & 0 & 0 & 卢 & 8 & $\circ$ & is & in & กิ & $\infty$ & ๑ & $?$ & ఒ & $\stackrel{\sim}{\sim}$ & & \\
\hline & $z$ & & & & 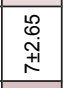 & & & & & 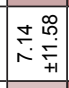 & 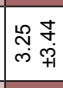 & & $\begin{array}{c}0 \\
\stackrel{0}{\dot{+}} \\
\dot{+}+1\end{array}$ & - & 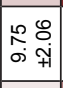 & 畩 & - & $\mid$ & $\sim$ & N ${ }_{\substack{f \\
+}}^{+}$ & 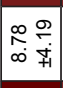 & 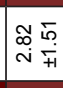 \\
\hline \multirow{2}{*}{$\bar{\Delta}$} & $\therefore$ & $\circ$ & 0 & 0 & $\stackrel{\llcorner}{N}$ & 0 & 0 & م & 0 & $\stackrel{\infty}{N}$ & 8 & 0 & 0 & 0 & 우 & i & $\stackrel{\circ}{\circ}$ & 8 & 0 & $\stackrel{\sim}{\sim}$ & & \\
\hline & $z$ & & & & 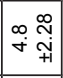 & & & $\sim$ & & $\stackrel{n}{m} \underset{+1}{m}$ & 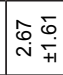 & & & & 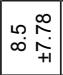 & $\stackrel{\sim}{\stackrel{5}{\frac{5}{+1}}}$ & 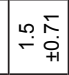 & 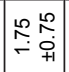 & & $\underset{\sim}{2} \stackrel{?}{?}$ & 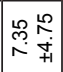 & 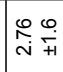 \\
\hline \multirow{2}{*}{ 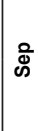 } & $\therefore$ & $\infty$ & 0 & 0 & 0 & 0 & ـ & ల్ & 0 & 우 & 吕 & $\infty$ & 0 & 0 & 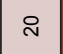 & $\stackrel{2}{2}$ & 0 & $R$ & 0 & $\stackrel{\sim}{\sim}$ & ৪ & \\
\hline & $z$ & - & & & & & $r$ & 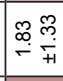 & & 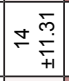 & 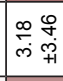 & - & & & 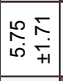 & 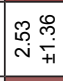 & & 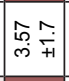 & & 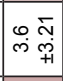 & 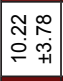 & 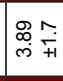 \\
\hline \multirow{2}{*}{$\frac{9}{8}$} & $\circ$ & 0 & 0 & 으 & 0 & م & م & \& & 0 & 6 & \& & $\circ$ & 0 & 0 & ه & 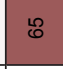 & 으 & $\ddot{\bullet}$ & 0 & 怘 & & \\
\hline & $z$ & & & 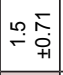 & & - & - & 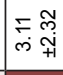 & & N & $\underset{\sim}{\mathbb{N}} \frac{8}{+1}$ & & & & $\nabla$ & 芯菅 & 욤 & 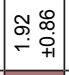 & & 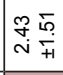 & 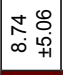 & م) \\
\hline \multirow{2}{*}{$\Xi$} & $\circ$ & $\circ$ & م & ㅇ & 0 & 0 & $\stackrel{\circ}{\circ}$ & $\stackrel{2}{\wedge}$ & 0 & 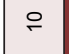 & 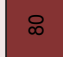 & 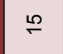 & 0 & 0 & ๘ & 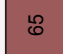 & 우 & 吕 & 0 & $\ddot{m}$ & & \\
\hline & $z$ & 웜 & - & 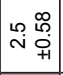 & & & 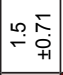 & 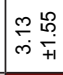 & & I & \begin{tabular}{ll}
$\stackrel{N}{N}$ \\
\multirow{r}{*}{$\underset{+}{\sim}$}
\end{tabular} & 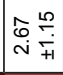 & & & $\infty$ & 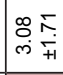 & 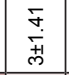 & 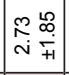 & & 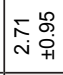 & 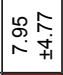 & $\ddot{\infty}$ \\
\hline \multirow{2}{*}{5} & $\therefore$ & ిల & 0 & g & 0 & 0 & กิ & & 0 & ిొ & & $\stackrel{2}{R}$ & 0 & 0 & 0 & $\stackrel{m}{m}$ & 우 & $\stackrel{\circ}{\llcorner}$ & 0 & 우 & 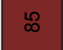 & \\
\hline & $z$ & 욧 & & 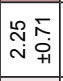 & & & 워N & 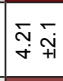 & & 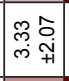 & 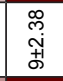 & 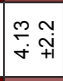 & & & & 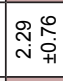 & 위N & 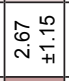 & & 윔 & 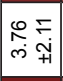 & స̂̃ \\
\hline \multirow[b]{2}{*}{$\sum^{\frac{\pi}{2}}$} & $\circ$ & g & 0 & 음 & 0 & 음 & 으 & $\mathfrak{R}$ & เ & \& & & ๕ & 0 & 0 & ๑ & $\stackrel{m}{\infty}$ & 으 & q & 0 & 0 & & \\
\hline & $z$ & 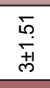 & & 워N & & 원 & 워N & 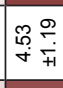 & N & 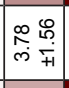 & 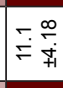 & 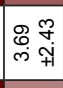 & & & $N$ & ஸ̊. & 욧 & 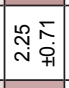 & & & 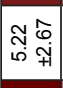 & 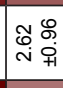 \\
\hline \multirow[b]{2}{*}{$\frac{0}{4}$} & $\circ$ & 8 & 0 & 0 & 0 & is & $\stackrel{2}{2}$ & $R$ & م & ๓ & & is & 0 & 0 & م & $\stackrel{R}{R}$ & 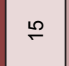 & 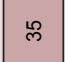 & 0 & 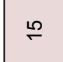 & & \\
\hline & $z$ & 兴旁 & & & & $N$ & 워N & 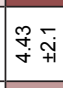 & N & $\left|\begin{array}{lll}0 & \widetilde{N} \\
0 & 0 \\
0 & +1\end{array}\right|$ & 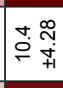 & 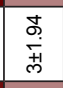 & & & $\sim$ & 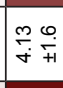 & 욧 & $\stackrel{\text { I }}{N}$ & & 위N & 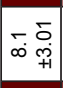 & 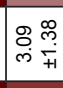 \\
\hline \multirow[b]{2}{*}{$\sum^{\pi}$} & $\circ$ & 0 & $\circ$ & 0 & 우 & 0 & 0 & g & 0 & $\stackrel{2}{\sim}$ & $\mathscr{\circ}$ & is & ஓ & 0 & 으 & & $\stackrel{2}{2}$ & ) & 0 & $\stackrel{2}{2}$ & & \\
\hline & $z$ & & & & 요 & & & 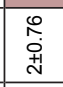 & & 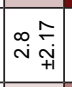 & 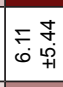 & $\sim \underset{\sim}{\stackrel{\overbrace{}}{T+1}}$ & 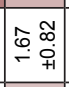 & & 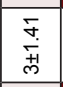 & 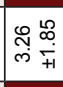 & 요 & 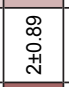 & & 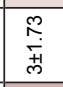 & $\hat{\infty} \underset{+}{\mathbb{N}}$ & $\underset{\substack{\infty \\
\sim}}{\stackrel{\infty}{+1}}$ \\
\hline \multirow{2}{*}{ 苂 } & $\circ$ & 0 & 0 & 。 & 우 & ○ & 0 & 0 & 0 & $\stackrel{2}{2}$ & is & 0 & $\stackrel{2}{2}$ & 0 & 으 & & 0 & 8 & 0 & లి & & \\
\hline & $z$ & & & & 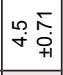 & & & & & $\begin{array}{lll}\hat{0} & - \\
\dot{0} & \stackrel{+1}{1}\end{array}$ & 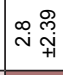 & & 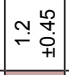 & & 온 & 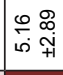 & & 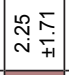 & & 宑 & 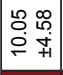 & 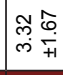 \\
\hline \multirow{3}{*}{ 으 } & $\circ$ & 0 & 0 & 0 & 음 & 0 & 0 & 0 & ○ & $\stackrel{2}{2}$ & 吕 & $\circ$ & 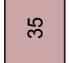 & 0 & $\stackrel{2}{2}$ & $\mathscr{\infty}$ & ద & in & 0 & 우 & ৪ & ৪ \\
\hline & $z$ & & & & 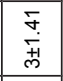 & & & & & 표 & 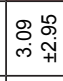 & & 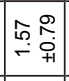 & & 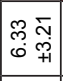 & 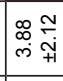 & $\sim$ & $\stackrel{\leftrightarrow}{\sim} \underset{+}{\tilde{T}}$ & & $\stackrel{\sim}{\sim} \underset{\sim}{\stackrel{N}{\sim}}$ & 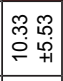 & 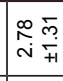 \\
\hline & & 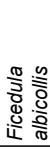 & & 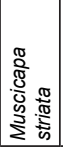 & 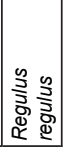 & 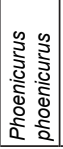 & 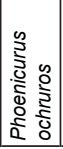 & 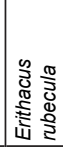 & 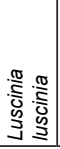 & 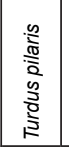 & 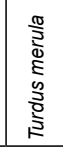 & 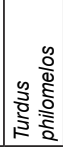 & 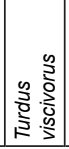 & 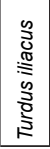 & 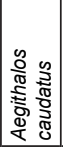 & 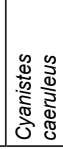 & 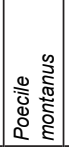 & 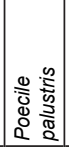 & 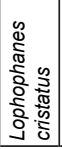 & 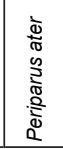 & 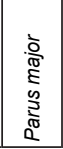 & 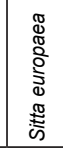 \\
\hline
\end{tabular}




\begin{tabular}{|c|c|c|c|c|c|c|c|c|c|c|c|c|c|c|c|c|}
\hline \multirow{2}{*}{$\stackrel{\mathscr{ٌ}}{\square}$} & $\circ$ & $\stackrel{\llcorner}{N}$ & ก & 0 & 0 & 0 & in & م & ๑ & 0 & $\stackrel{R}{R}$ & ه & 0 & ఋ & ద & 0 \\
\hline & $z$ & 䒪菅 & 욤 & & & & - & 芯 & N & & 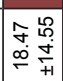 & $m$ & & 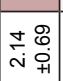 & - & \\
\hline \multirow[b]{2}{*}{ 울 } & $\circ$ & 电 & $\stackrel{2}{\llcorner}$ & 0 & ص & 0 & $\circ$ & 0 & 음 & 0 & ஜீ & $\stackrel{2}{2}$ & 0 & 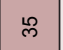 & 음 & ○ \\
\hline & $z$ & 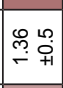 & 요 & & - & & & & 占 & & $\mid \begin{array}{ll}\hat{N} & \hat{0} \\
0 & 0 \\
0 & 0 \\
+ & +1 \\
\end{array}$ & $\begin{array}{l}0 \\
0 \\
+ \\
+ \\
⿱ 亠 䒑 \\
\end{array}$ & & 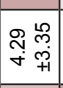 & 욤 & \\
\hline \multirow{2}{*}{$\overline{0}$} & $\circ$ & q & న & n & 우 & 0 & ○ & $\circ$ & 0 & 0 & 员 & $\stackrel{\circ}{\circ}$ & 0 & $\stackrel{2}{2}$ & $\stackrel{m}{\infty}$ & 。 \\
\hline & z & 욤 & 표 & $\simeq$ & 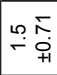 & & & & & & 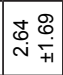 & 文 & & 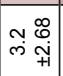 & 离 & \\
\hline \multirow{2}{*}{ ఏ } & $\therefore$ & ळ & $\stackrel{\sim}{\text { N }}$ & 0 & 0 & 0 & 0 & 0 & 0 & 0 & $\stackrel{\sim}{N}$ & ه & 0 & 0 & 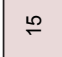 & 。 \\
\hline & $z$ & 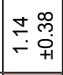 & 판 & & & & & & & & 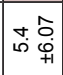 & - & & & 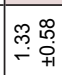 & \\
\hline \multirow{2}{*}{$\stackrel{8}{2}$} & $\therefore$ & m & $\stackrel{\llcorner}{N}$ & 0 & ص & 0 & 0 & 0 & م & 0 & เ & 0 & 0 & 0 & 움 & ○ \\
\hline & $z$ & 요 & 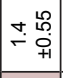 & & $\infty$ & & & & - & & $N$ & & & & 足 & \\
\hline \multirow[b]{2}{*}{$\bar{\Xi}$} & $\therefore$ & ది & $\stackrel{\mathfrak{N}}{2}$ & 0 & ిలి & 0 & 0 & 0 & ๑ & 0 & $\stackrel{20}{2}$ & $\stackrel{6}{\leftarrow}$ & 0 & 0 & $\stackrel{2}{2}$ & 0 \\
\hline & $z$ & 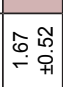 & 워N & & 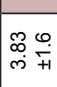 & & & & $N$ & & $\begin{array}{l}\begin{array}{l}0 \\
+ \\
⿱ 亠 䒑 \\
y \\
y\end{array} \\
\end{array}$ & ₹ै & & & 웟 & \\
\hline \multirow{2}{*}{ 今ે } & $\circ$ & 우 & م & 0 & & 0 & 0 & 0 & 0 & is & ه & $\stackrel{\sim}{\sim}$ & 0 & 0 & ని & \llcorner \\
\hline & $z$ & I & r & & $\stackrel{\substack{N \\
N}}{ }$ & & & & & $N$ & $N$ & $\stackrel{\infty}{\sim} \underset{\sim}{\stackrel{\Gamma}{+}}$ & & & 요 & $\sim$ \\
\hline \multirow{2}{*}{$\sum_{\Sigma}^{\pi}$} & $\circ$ & 으 & is & 。 & & 0 & $\circ$ & 0 & م & $\div$ & 0 & is & 0 & 0 & \& & 0 \\
\hline & $z$ & $\stackrel{\text { I }}{N}$ & $\sim$ & & 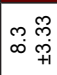 & & & & $N$ & I & & 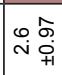 & & & 윔 & \\
\hline \multirow[b]{2}{*}{ 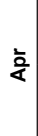 } & $\therefore$ & iి & r & 0 & & ○ & 0 & 0 & n & $\stackrel{\circ}{\llcorner}$ & 0 & 吕 & 0 & o & $\infty$ & o \\
\hline & $z$ & $\begin{array}{ccc}\infty & \infty \\
& 0 \\
\sim & +1\end{array}$ & I̊ & & 隹离 & & & & $N$ & 원 & & 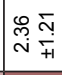 & & & 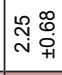 & \\
\hline \multirow{2}{*}{$\sum^{\pi}$} & $\therefore$ & $\stackrel{\text { న }}{2}$ & is & 0 & $\bullet$ & ๑ & 0 & 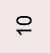 & is & is & $\stackrel{m}{\infty}$ & ¿ & n & 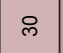 & o & ○ \\
\hline & $z$ & \begin{tabular}{cc}
0 & 0 \\
\hdashline \\
\hdashline \\
+1
\end{tabular} & - & & 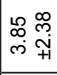 & - & & $\underset{+}{\mp}$ & - & - & 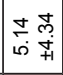 & 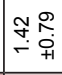 & $\sim$ & 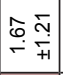 & 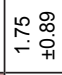 & \\
\hline \multirow[b]{2}{*}{ 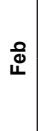 } & $\therefore$ & œ & 우 & 0 & 0 & 0 & $\circ$ & $\circ$ & ๑ & 0 & 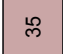 & กิ & 0 & q & 0 & 0 \\
\hline & $z$ & 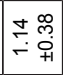 & 욤 & & & & & & $N$ & & 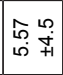 & 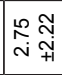 & & $\stackrel{\infty}{\infty} \underset{\sim}{\stackrel{i}{+}} \bar{\sim}$ & & \\
\hline & $\circ$ & m & 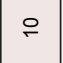 & เ & 0 & 0 & 0 & 0 & 0 & 0 & 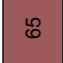 & م & 0 & $\stackrel{2}{\sim}$ & $\stackrel{5}{\llcorner}$ & 0 \\
\hline & $z$ & 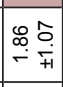 & 욛 & ه & & & & & & & 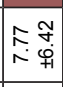 & $m$ & & 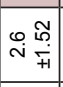 & 隽 & \\
\hline & & 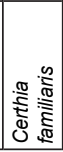 & 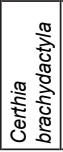 & 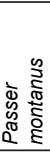 & 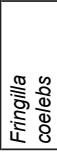 & 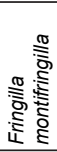 & 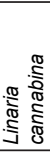 & 总 & 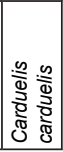 & 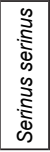 & 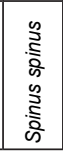 & 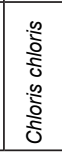 & 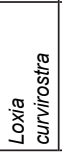 & 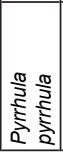 & 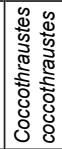 & 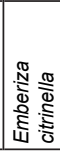 \\
\hline
\end{tabular}

